\title{
Install identitas pribumi dalam praktik komunikasi etnik Tionghoa di Bima, Indonesia
}

\author{
Kadri $^{1}$, Abdul Wahid ${ }^{2}$ \\ 1,2Universitas Islam Negeri Mataram, Indonesia
}

\begin{abstract}
ABSTRAK
Fenomena interaksi komunitas Tionghoa di Bima menarik untuk dipelajari karena kenyataan minimnya konflik antara etnik Tionghoa dengan masyarakat lokal. Studi ini bertujuan untuk mengungkap fenomena installing identitas etnik yang dilakukan warga Tionghoa dalam komunikasinya dengan masyarakat pribumi Bima, Nusa Tenggara Barat sebagai upaya untuk menjadi orang Bima secara sosial dan psikis. Riset ini menggunakan metode kualitatif, dengan tradisi fenomenologi ini menjadikan 20 orang etnik Tionghoa dan 15 orang etnik Bima sebagai informan untuk diwawancarai dan diamati sejak Oktober 2019 hingga Juli 2020. Hasil riset menunjukkan bahwa etnik Tionghoa di Bima melakukan installing identitas etnik dengan cara menginternalisasi nilai-nilai budaya Bima, terlibat dalam kegiatan sosial dan budaya, mengambil bagian dalam hobi komunal etnik Bima, dan menggunakan bahasa daerah di ruang publik secara intens. Meskipun proses installing identitas etnik telah mengefektifkan komunikasi warga Tionghoa dengan masyarakat Bima, namun bukan berarti etnik Tionghoa serius meng-install dirinya menjadi orang Bima karena hal tersebut hanya mereka lakukan di ruang publik sebagai bentuk pengelolaan kesan dengan motif subjektif dan pragmatis agar mereka sukses berbisnis dan bisa diterima di kalangan masyarakat lokal tanpa resistensi. Secara teoretis, studi ini turut memperkaya kajian komunikasi antarbudaya dengan model pengelolaan kesan etnik Cina yang ditemukannya. Secara pragmatis, studi ini penting sebagai referensi bagi etnik Tionghoa dalam membangun komunikasi yang efektif dengan komunitas lokal di Indonesia.
\end{abstract}

Kata-kata Kunci: Bima; installing identitas etnik; komunikasi; pengelolaan kesan; Tionghoa

\section{Installing indigenous identities into communication practices among Chinese in Bima, Indonesia}

\begin{abstract}
The way Chinese community in Bima interact to natives is interesting to be studied as there is minimal conflict between ethnic Chinese and local communities. This study aims to describe the social practices among Chinese ethnic group in Bima which are considered as a mechanism for becoming insider, namely installing identity. This mechanism is manifested into the communication in the public spheres, symbolizing social engagements between two ethnic groups, Chinese and local Bimanese. This research uses the method kualitatif, phenomenological research is being enriched by interviewing and observing 35 people from both Chinese and Bimanese groups in short term period of fieldwork from October 2019 to July 2020. Research findings show that Chinese living in Bima build their identities by internalizing cultural values of Bima, having intense social engagement such as taking part in the communal hobbies of the Bimanese and using local languages in public spaces intensively. Even though the process of installing ethnic identities has streamlined the communication of Chinese citizens with the Bimanese community, it does not necessarily mean that Chinese are seriously devoted to transforming themselves into "real" Bimanese. In fact, they only do the above-mentioned strategies in public space as a form of impression management driven by business motives and economic interests. Theoretically, this study also enriches the study of intercultural communication with the impression management model of Chinese ethnic that it finds. Pragmatically, this study is important as a reference for Chinese in building effective communication with local communities in Indonesia.
\end{abstract}

Keywords: Bimanese; installing ethnic identity; communication; impression management; Chinese

Korespondensi: Dr. Kadri, M.Si. Universitas Islam Negeri Mataram. Jl. Pendidikan No. 35 Mataram, Nusa Tenggara Barat.Email: kadri@uinmataram.ac.id 


\section{PENDAHULUAN}

Etnik Cina (Tionghoa) di Indonesia telah mengalami pergumulan kehidupan sosiokultural yang begitu intens, bertautan dengan berbagai kebijakan yang mengatur kehidupan sosial mereka dari pemerintah. Mereka juga berhadapan dengan atmosfer kehidupan sosial yang beragam sesuai keragaman masyarakat Indonesia, yang membuat mereka dituntut mempertaruhkan nilai-nilai kultural dan identitas yang mereka miliki. Setelah memperoleh efek dari pendikotomian ras dan etnik saat masa kolonial (Basundoro, 2012), yakni dikotomi pribumi dan non-pribumi, etnik Tionghoa dipaksa berasimilasi oleh rezim Orde Baru (Fittrya, 2013). Hubungan sosial etnik Tionghoa dengan warga pribumi tercatat dinamis. Etnik Tionghoa yang telah menyebar ke seluruh pelosok negeri tidak hanya mencatat sukses di dunia bisnis pada setiap daerah (Seng, 2013), tetapi juga tercatat pernah menjadi korban dari kerusuhan sosial yang berlangsung di setiap wilayah, seperti peristiwa kerusuhan Mei 1998 yang berpusat di Jakarta (Titulanita et al., 2015) dan merembes ke beberapa daerah di tanah air (Putro et al., 2017). Kasus-kasus tersebut menunjukkan masih adanya persoalan psikologis yang menjadi ganjalan dalam mewujudkan komunikasi dan relasi sosial yang harmonis antara masyarakat pribumi dengan etnik Tionghoa.

Beberapa riset tentang komunikasi antaretnik Tionghoa dan etnik pribumi menemukan adanya stereotip yang menyertai interaksi dan komunikasi keduanya. Juditha misalnya menemukan sikap stereotip yang menjadi penyebab konflik antara etnik Tionghoa dengan masyarakat Makassar (Juditha, 2015). Prasangka dan stereotip merupakan salah satu rintangan dalam pembentukan komunikasi yang efektif (Effendy, 2017), dan menjadi penghambat potensial dalam komunikasi antarbudaya (Purwasito, 2015). Masyarakat Bima dan etnik Tionghoa sebagai partisipan komunikasi diasumsikan mampu meminimalisir stereotip dalam komunikasi antaretnik sehingga interaksi mereka di Bima berlangsung dengan konflik minimal.

Konflik antaretnik Tionghoa dengan masyarakat pribumi bukanlah peristiwa rutin. Konflik rasial yang melibatkan etnik Tionghoa dan masyarakat lokal hanya letupan sesaat yang muncul sebagai reaksi atas sikap dan perilaku diskriminatif oknum Tionghoa terhadap masyarakat lokal. Peristiwa-peristiwa kelam seperti itu tidak seberapa bila dibandingkan dengan aksi-aksi kolaboratif dan kerja sama etnik Tionghoa dengan masyarakat lokal di setiap daerah. Bima adalah salah satu dari beberapa daerah yang tercatat memiliki konflik minimal dengan etnik Tionghoa.

Tidak ditemukan peristiwa konflik yang serius antara etnik Tionghoa dan warga pribumi di daerah paling Timur Pulau Sumbawa tersebut. Hanya tercatat aksi-aksi kecil di depan toko milik warga etnik Tionghoa sebagai reaksi masyarakat Bima terhadap kerusuhan 1998 yang berpusat di Jakarta. Daerah Bima dapat dikatakan sebagai wilayah yang nyaman bagi etnik Tionghoa dalam mengembangkan bisnisnya dan mereka bisa hidup berdampingan dengan masyarakat mayoritas, baik dalam konteks hubungan antara penjual dan pembeli maupun sinergi bisnis bersama pengusaha lokal. Terbukti hingga saat ini, warga etnik Tionghoa masih eksis pada beberapa sektor bisnis strategis di Bima seperti jasa konstruksi, toko grosir pakaian, transportasi, otomotif, elektronik, dan beberapa jenis usaha strategis lainnya. Bisnis yang sama juga dilakukan oleh pengusaha lokal, namun modal dan kapasitas usahanya masih di bawah pengusaha dari etnik Tionghoa. Fakta ini menunjukkan bahwa etnik Tionghoa dan masyarakat Bima bisa bekerja sama dan saling menghargai tanpa saling mengganggu eksistensi dan profesi masing-masing.

Etnik Tionghoa yang ada di Bima tidak hanya menoreh sukses di bidang ekonomi tetapi juga masuk secara sosial, bisa memahami selera kultur komunal masyarakat Bima. Hal ini dibuktikan dengan kesediaannya untuk terlibat dan mengambil bagian dalam aktivitas yang menjadi kearifan lokal masyarakat Bima seperti acara selamat kelahiran dan sunatan, resepsi pernikahan, ritual penurunan kapal, dan acara tasyakuran lainnya, hingga kegiatan melayat di keluarga duka. Lebih dari itu, etnik Tionghoa di Bima terlibat dan mengambil bagian dalam olahraga dan pacuan kuda, yang merupakan olahraga dan pertunjukan tradisional yang sangat disukai oleh masyarakat Bima (Wahid, 2015). Sebagian besar dari etnik Tionghoa memiliki kuda pacuan, yang dipelihara oleh warga lokal, dengan itu mereka berinteraksi dengan warga (penonton) di arena pacuan kuda, 
dan bercengkerama dengan pemilik kuda pacuan lainnya yang berasal dari masyarakat pribumi. Realitas ini paling tidak mengindikasikan adanya pembauran etnik Tionghoa dalam jantung aktivitas khas masyarakat lokal, sekaligus memperluas ruang-ruang komunikasi mereka dengan warga pribumi.

Sukses etnik Tionghoa untuk menjalani dan mengembangkan bisnis di Bima dan pilihannya untuk terlibat dan membaur bersama masyarakat pribumi dalam ruang publik tradisional seperti pacuan kuda merupakan wujud kompetensi komunikasinya, terutama komunikasi interpersonal. Bagi etnik nonpribumi seperti warga Tionghoa, kompetensi komunikasi antara lain diwujudkan lewat kemampuan mengonstruksi identitas etnik saat berkomunikasi dengan masyarakat pribumi. Secara sosial, etnik Tionghoa di Bima diasumsikan mereidentifikasi identitas etniknya sebagai upaya subjektif mereka memaknai eksistensinya yang lama di Bima, sekaligus untuk kepentingan pragmatis mereka selama berinteraksi di ruang publik bersama masyarakat setempat.

Upaya reidentifikasi identitas etnik yang dilakukan etnik Tionghoa di Bima dimungkinkan bila kelompok etnik dimaknai secara longgar. Kelompok-kelompok etnik bukan selalu merupakan suatu kelompok (tribe) yang sederhana dengan budaya yang tersusun rapi serta wilayah teritorial yang definitif, serta mudah dibedakan batas-batasnya satu dengan lain. Bahkan kelompok-kelompok etnik tidak hanya didasarkan pada teritorial yang ditempatinya atau suatu sistem rekrutmen baku yang diberlakukan, tetapi pada pernyataan dan pengakuan yang berkesinambungan mengenai identifikasi dirinya (Barth, 1969).

Pemaknaan identitas etnik dari Bart seperti di atas menegaskan bahwa secara longgar identitas etnik tidak berhubungan dengan latar belakang biologis yang taken for granted tetapi dapat dikonstruksi atau di-install sehingga tadinya outsider menjadi insider (Fox, 2008) dengan motif tertentu berdasarkan kepentingankepentingan subjektif setiap individu, walaupun dengan cara menyembunyikan identitas asli agar bisa diterima dan hidup berdampingan dengan etnik mayoritas seperti yang dilakukan oleh etnik Tionghoa di Madura (Hidayat dan Farid, 2021).

Interaksi etnik Tionghoa dengan masyarakat Bima yang menunjukkan harmoni hingga saat ini diasumsikan terjadi karena kemampuan etnik Tionghoa untuk melakukan installing identitas etnik sekaligus mengelola identitas etnik di ruang publik. Berkaitan dengan asumsi tersebut, maka riset ini bertujuan untuk mengungkap fenomena installing identitas etnik yang dilakukan warga Tionghoa sebagai upayanya untuk menjadi orang Bima di ruang publik. Riset ini dapat mengisi kelangkaan risetriset tentang etnik Tionghoa di Bima, terutama terkait dengan fenomena komunikasi antaretnik atau komunikasi antarbudaya. Lebih dari itu, temuan dalam riset ini dapat dijadikan sebagai referensi tentang praktik baik (best practices) bagi etnik Tionghoa lainnya di tanah air dalam membangun komunikasi yang efektif dengan masyarakat lokal sehingga konflik sosial yang melibatkan etnik Tionghoa dan masyarakat pribumi dapat diminimalisir.

\section{METODE PENELITIAN}

Riset ini menggunakan metode penelitian kualitatif dengan tradisi penelitian fenomenologi. Pilihan tradisi penelitian fenomenologi dianggap tepat untuk mengungkap pandangan dan tindakan subjektif warga etnik Tionghoa saat berkomunikasi pada ruang publik di Bima. Fenomenologi sebagai tradisi penelitian lebih difokuskan untuk mengungkap kesadaran dan pengalaman subjektif seseorang atau sekelompok orang mengenai fenomena tertentu (Sobur, 2013), atau sebagai istilah generik untuk merujuk kepada semua pandangan ilmu sosial yang menempatkan kesadaran manusia dan makna subjektifnya sebagai fokus untuk memahami tindakan sosial (Mulyana, 2018).

Penelitian berlangsung di Kota Bima dan Kabupaten Bima mulai Oktober 2019 hingga Juli 2020, dengan menjadikan 20 orang etnik Tionghoa (3 orang generasi pertama dan 17 orang generasi kedua atau yang lahir di Bima) dan 15 orang warga lokal Bima sebagai informan. Informan dipilih secara purposive sampling dengan memilih warga Tionghoa yang aktif di ruang publik seperti pedagang, aktivis sosial, dan penggemar kuda pacuan. Warga lokal (etnik Bima) yang dipilih menjadi informan adalah aktivis, karyawan toko, dan penggemar kuda pacuan. Pengamatan, wawancara 
mendalam, dan dokumentasi merupakan tiga teknik pengumpulan data yang digunakan dalam riset ini. Analisis data dilakukan melalui empat tahapan analisis yaitu pengumpulan data, kondensasi data, penyajian data, dan penarikan kesimpulan (Miles et al., 2014).

\section{HASIL DAN PEMBAHASAN}

Identitas dan komunikasi adalah dua ranah pergumulan antara etnik Tionghoa dengan masyarakat Bima. Etnik Tionghoa di Bima dikenal sebagai warga yang mampu beradaptasi dengan budaya lokal, memaknai dan menegosiasikan identitas etniknya secara fleksibel saat berkomunikasi di ruang publik. Nilai-nilai inklusif, kosmopolitan, fleksibel, dan partisipatif di kalangan masyarakat Tionghoa memang telah menjadi corak komunal yang menandai pergaulan sosial mereka dalam masyarakat plural. Karakter-karakter inilah yang menjadi penyebab keberterimaan masyarakat Muslim terhadap etnik Tionghoa di Indonesia (Weng, 2019). Pandangan tersebut dibuktikan oleh sosok Sct, seorang dokter keturunan Tionghoa yang akrab dan dicintai oleh masyarakat Bima, terutama yang menjadi pasiennya di tempat Beliau membuka praktek. Sct dinilai sopan, dermawan, dan lincah berbahasa Bima, baik saat melayani pasiennya maupun ketika Beliau berinteraksi dengan masyarakat Bima di ruang public (wawancara dengan Rsl, 2019).

Sikap kultural etnik Tionghoa seperti ini menjadi celah perjumpaan dengan kultur orang Bima yang juga berkarakter terbuka, egaliter, dan inklusif. Modal dan atmosfer kultural ini tetap saja harus mereka pupuk agar pergaulan multikultural di antara mereka dan penduduk lokal tetap tumbuh subur. Komunitas etnik Tionghoa terlihat mampu mempraktikkan komunikasi yang sesuai dengan karakter orang Bima. Pada sisi orang Bima sendiri berlaku norma-norma sosial yang mendukung tumbuhnya pergaulan multikultural yang harmonis dan produktif. Terdapat adagium di kalangan masyarakat seperti: "Tahompara nahu sura dou labo dana" (jangan suka mendahulukan diri sendiri, dahulukan kepentingan orang lain), atau ungkapan di kalangan rakyat, "Sura na tahompa dou nami mancewi taho wali" (kalau orang lain menunjukkan kebaikan/bersahabat dengan kita, maka kita harus mebalasnya dengan lebih baik). Nilai-nilai kearifan lokal masyarakat Bima seperti ini dapat menjadi faktor pendukung bagi efektivitas proses installing identitas etnik Tionghoa di Bima.

Etnik Tionghoa di Bima memang tidak hanya dikenal sebagai komunitas yang sukses dalam dunia bisnis tetapi juga terampil dalam membangun hubungan sosial. Hubungan antara dunia bisnis dengan komunikasi tampaknya menjadi kesadaran dasar. Hal ini terlihat dari kesediaan mereka untuk terlibat dalam setiap kegiatan sosial di lingkungannya. Salah satu cara etnik Tionghoa beradaptasi dengan masyarakat Bima adalah dengan berpartisipasi dalam setiap kegiatan apapun yang diselenggarakan oleh masyarakat setempat. Salah seorang warga etnik Tionghoa berinisial Ing (wawancara 2019) mengakui kalau ia selalu menjaga hubungan sosial dengan seluruh masyarakat Bima dengan cara selalu hadir dan berpartisipasi dalam setiap acara yang digelar masyarakat Bima seperti acara pernikahan, kematian, dan peringatan hari besar Islam, serta rutin membagi hadiah lebaran pada setiap Hari Raya Idul Fitri.

Pengakuan etnik Tionghoa yang berprofesi sebagai pedagang di atas menunjukkan adanya kesediaan mereka untuk berinteraksi dan terlibat dalam kegiatan sosial budaya masyarakat lokal, sekaligus membangun hubungan emosional dengan masyarakat Bima, yang terlihat terbuka menerima kehadiran mereka. Proses pembauran ini telah menghilangkan jarak sosial antara etnik Tionghoa dengan masyarakat lokal sehingga perbedaan identitas etnik di antara mereka tidak menjadi penghalang dalam melakukan komunikasi sosial. Fenomena inilah yang antara lain turut berkontribusi menciptakan harmoni sosial di Bima, karena integrasi sosial terjadi ketika ada kesukarelaan sosial dalam menerima setiap individu atau kelompok yang beragam untuk terlibat aktif dalam semua kegiatan sosial (Pranawati dan Abubakar, 2011)

Beberapa warga etnik Tionghoa tercatat secara aktif dalam aktivitas sosial kemasyarakatan. Mereka mengambil peran langsung dan intensif dalam berbagai kegiatan bersama masyarakat Bima, bahkan terlihat lebih aktif dibandingkan dengan masyarakat lokal. Salah seorang informan yang termasuk dalam kategori ini adalah Bko. Bko adalah salah seorang warga Tionghoa yang dikenal sebagai aktivis di Bima dan telah malang melintang di 
beberapa organisasi sosial dan politik. Lelaki berperawakan sedang tersebut pernah menjadi pengurus Komite Nasional Pemuda Indonesia (KNPI) Kabupaten Bima, senang mengikuti kegiatan politik, dan beberapa kali terlibat sebagai tim sukses salah satu pasangan calon kepala daerah di kota maupun kabupaten Bima. Keaktifannya berinteraksi dengan warga Bima membuat Bko tidak memiliki jarak dengan mereka. Bko telah diterima seperti saudara sendiri oleh orang Bima, bahkan tidak jarang Bko disapa dengan "muma" oleh orang Bima. Muma adalah nama atau panggilan kehormatan kepada orang Bima yang telah berhaji dan ditokohkan oleh masyarakat.

Manfaat pragmatis dari pergaulannya ini dirasakan sendiri oleh Bko ketika terjadi kerusuhan massa tahun 1998 di kota Bima. Menurutnya, saat itu orang-orang Tionghoa mengalami ketakutan dan kepanikan yang luar biasa, tetapi Bko tidak merasakan kekhawatiran sedikit pun. Bko biasa berjalan dan membaur dengan para demonstran tanpa seorang pun yang mengganggunya. Kedekatan emosional dengan masyarakat lokal inilah yang membuat Bko tidak mengalami penolakan saat mempersunting gadis Bima sebagai istrinya.

Pengalaman interaksi dengan masyarakat Bima juga diceritakan oleh Bnt dan istrinya. Menurut mereka, selama hidup di Bima tidak pernah memiliki persoalan yang serius dengan masyarakat setempat. Mereka sangat senang bisa hidup bersama masyarakat Bima karena bagi mereka semua orang adalah temannya.

Kalau ada undangan dari kerabat kami selalu hadiri, dan kalau kami punya acara pasti mengundang warga dan tetangga. Semua agama kami hormati. Kalau ada lebaran kami keluarkan hágala (hadiah lebaran berupa uang). Dengan masyarakat kami akrab. Kalau ada orang mati kami pergi melayat, kalau ada orang kawin kami hadiri pestanya. Ya kalau kita hadiri orang kawin selalu disapa sama orang Bima karena semua mengenal kami. Saat kami pulang dari pantai Kalaki setiap pagi untuk mandi air laut, kami selalu mengajak setiap orang yang berjalan di jalan raya untuk naik mobil dan diantar sampai di mana tujuan yang bersangkutan (wawancara dengan Bnt, 2020).

Pengalaman keluarga etnik Tionghoa di atas menunjukkan keakraban dan keaktifan mereka dengan masyarakat lokal di Bima. Teknik dan pilihan konten komunikasi pun mencerminkan kedekatan mereka dengan warga Bima. Perbedaan agama dan asal-usul atau etnik tidak menjadi hambatan dalam komunikasi mereka. Terbangunnya komunikasi yang baik antara etnik Tionghoa dan warga Bima tidak hanya karena egaliter-nya etnik Tionghoa dalam berinteraksi tetapi juga karena adanya sikap egalitarian warga Bima. Apabila asumsi ini diadopsi untuk memotret fenomena installing identitas etnik Tionghoa maka dapat dikatakan bahwa kesuksesan proses installing identitas etnik Tionghoa di Bima tidak hanya karena usaha mereka tetapi juga karena adanya sikap egaliter dan keberterimaan masyarakat Bima terhadap keberadaan etnik Tionghoa di daerahnya. Ada kesadaran intersubjektif antara etnik Tionghoa dan masyarakat lokal (Bima) yang berkontribusi dalam proses installing identitas etnik Tionghoa. Fenomena ini menegasi asumsi teori fenomenologi Schutz yang menyebut bahwa dunia sosial terbentuk dari suatu kesamaan dan kebersamaan (common and shared) di antara para aktor dari proses pemaknaan sadar intersubjektif di antara mereka (Sobur, 2013).

Hubungan baik dengan masyarakat Bima selalu ingin etnik Tionghoa jaga. Persamaan, kedamaian, dan persahabatan adalah dambaannya karena mereka telah merasa sebagai orang Bima, seperti halnya warga yang berketurunan Bima. Kebaikan dan keramahan etnik Tionghoa diakui oleh warga Bima yang berprofesi sebagai karyawan toko milik warga Tionghoa.

"Saya tidak merasa ada perbedaan antara orang Tionghoa dengan orang Bima, karena sejak saya dipanggil bekerja di tokonya hingga sekarang ini dia baik sama saya. Saya tidak pernah kena marah, dan kalaupun marah karena kita salah itu biasa. Dia baik sekali. Kalau saya sakit dia jenguk dan diberikan uang untuk berobat. Jadi saya senang bekerja dengan orang Cina (Wawancara dengan Rmn, 2019)."

Pengakuan warga Bima di atas semakin mempertegas sikap dan perilaku etnik Tionghoa yang didasarkan pada nilai-nilai budaya dan etos sosial tertentu yang mereka anut. Mereka juga menerapkan nilai budaya itu dalam konteks masyarakat lokal yang juga meyakini suatu tata nilai dan norma yang bercirikan keguyuban dan egalitarian. Rasa dekat dan bersahabat dengan 
warga lokal adalah hasil dari sebuah interaksi atas dasar moralitas ketersalingan (resiprokal), dan ini pada gilirannya meminimalisir perbedaan etnik di antara etnik Tionghoa dengan etnik Mbojo. Jarak sosial yang selalu menghasilkan konflik berhasil ditepis dengan kearifan sosial yang ditunjukkan lewat kebersamaan dalam berkomunikasi di ruang publik.

Kebersamaan tersebut direkatkan dengan adanya upaya etnik Tionghoa untuk mengidentifikasi dirinya sebagai orang Bima dan pada saat bersamaan masyarakat Bima menganggapnya sebagai teman dan saudara. Keberterimaan orang Bima terhadap warga Tionghoa terabadikan dalam sapaan $b a b a$ (kakak) di depan nama untuk semua warga Tionghoa yang berjenis kelamin laki-laki, misalnya Baba Nge, Baba Ko, Baba Afang, dan lain sebagainya. Pada umumnya masyarakat Bima hanya memanggil baba tanpa menyertakan nama panggilan dari etnik Tionghoa. Menurut kebiasaan orang Bima, memanggil seseorang dengan kata baba merupakan bentuk penghargaan dan rasa hormat, sekaligus sebagai wujud kedekatan secara emosional dengan yang bersangkutan. Sapaan akrab penuh penghargaan terhadap etnik Tionghoa seperti di atas merupakan bentuk lain dari kearifan lokal Bima yang turut berkontribusi bagi efektivitas installing identitas etnik warga Tionghoa di Bima.

Keterlibatan etnik Tionghoa dalam kegiatan sosial dan budaya masyarakat Bima tidak hanya dimaknai sebagai upaya mereka mengkonstruksi identitas atau installing identity dari identitas outsider (Tionghoa) menjadi identitas insider (Bima) tetapi juga menunjukkan kompetensi komunikasinya. Keterlibatan etnik Tionghoa dalam kegiatan sosial di tengah kesibukan bisnisnya dapat dimaknai sebagai upaya mereka menghindari klaim eksklusif sekaligus memperpendek jarak sosial dari masyarakat setempat. Keakraban etnik Tionghoa dengan masyarakat Bima saat kegiatan sosial telah menghilangkan jarak etnik mereka yang berbeda. Mereka melebur menjadi satu komunitas yang bekerjasama, meskipun selama proses kebersamaan tersebut tidak ditemukan fenomena asimilasi dan akulturasi budaya di dalamnya. Fenomena kebersamaan yang berlangsung hanya sebagai bentuk adaptasi dan installing identitas etnik yang dilakukan etnik Tionghoa dan keberterimaan etnik Bima terhadap upaya tersebut.

Telah menjadi pengetahuan umum (common sense) bahwa antara warga Tionghoa dan masyarakat Bima memiliki identitas etnik berbeda. Meskipun saat ini pengakuan terhadap eksistensi etnik Tionghoa secara administratif, politik, dan kultural sudah lebih baik dari masa (rezim) Orde Baru dan mengarah ke kebijakan multikulturalisme, namun etnik Tionghoa di Bima masih menginginkan pengakuan totalitas secara sosial dari masyarakat lokal tentang eksistensinya yang tidak terpisahkan dari daerah di mana mereka hidup. Pintu masuk kepada pergaulan multikultural ini antara lain melalui pendekatan hobi atau kesamaan gaya hidup. Memiliki hobi yang sama membuat beberapa orang individu memiliki kesempatan untuk bersama secara kontinu. Momentum inilah yang memungkinkan terjalinnya hubungan emosional di antara semua orang yang memiliki hobi yang sama.

Hal inilah yang dirasakan oleh beberapa orang etnik Tionghoa di Bima yang memiliki hobi memelihara kuda pacuan. Hobi ini membuat mereka memiliki waktu yang banyak untuk berhubungan, berkomunikasi, dan berinteraksi dengan warga Bima, baik di kandang kuda maupun di arena pacuan kuda. Pacuan kuda adalah salah satu olahraga, hiburan, dan kontestasi yang popular dan digemari oleh masyarakat Bima. Arena pacuan kuda merupakan tempat berkumpul masyarakat penggemar kuda di seluruh Kabupaten dan Kota Bima, bahkan dari seluruh penggemar kuda yang ada di Pulau Sumbawa. Mereka adalah pemilik kuda pacuan, penghobi, pebisnis kuda, penjudi, dan pihak-pihak yang mengais rezeki dari event tersebut.

Interaksi multikultural yang penuh kekerabatan, rukun, dinamis, dan elegan layaknya suasana kesenangan dengan mudah dapat ditemukan di arena pacuan kuda. Jalinan komunikasi antar mereka begitu erat, kuat, dan penuh kekerabatan. Cakupan pergaulan mereka bukan saja di arena pacuan kuda, tetapi juga di luar. Meskipun komunitas mereka bukan perkumpulan yang terorganisir tetapi jaringan hubungan ini telah membentuk suatu pola hubungan sosial antar mereka berdasar kesamaan hobi dan kepentingan. Di luar arena dan event pacuan kuda mereka biasanya berkumpul, kongkow-kongkow di tempattempat di mana kuda-kuda terkenal biasanya 
dipelihara. Tempat-tempat biasanya digunakan oleh para penghobi kuda sebagai rendezvous (tempat bertemu) antara lain kebun dan rumah pemilik kuda atau di tempat lainnya yang mereka sepakati.

Baik di pacuan kuda maupun di rendezvousrendezvous itu, beberapa etnik Tionghoa sering melibatkan diri dengan anggota komunitas lain, dan mereka berkomunikasi tanpa ada sekatsekat kelas sosial di antara mereka. Fenomena di kebunnya Bna, misalnya, suasana cengkerama antara Baba (panggilan untuk lelaki Tionghoa) dengan anak buahnya terlihat egaliter, tidak ada pola-pola perintah layaknya hubungan patronklien atau antara atasan-bawahan, dan juga tidak ada pengelompokan berdasarkan etnis. Saat bergabung dengan komunitas-komunitas ini, para etnik Tionghoa tidak membawa identitas-identitas yang menunjukkan mereka berbeda secara sosial-ekonomi dengan kalangan masyarakat yang umumnya berbeda kelas dengan mereka. Mereka datang tidak dengan pakaian yang khas, kendaraan yang berbeda, dan tata cara penyambutan yang membedakan. Satu-satunya yang membedakan mereka adalah warna kulit dan bentuk fisiologi. Mereka gemar menggunakan pakaian kasual yang informal, menggunakan kendaraan sepeda motor, tidak disambut sebagaimana kalau kelompok sosial lain, misalnya para pemilik kuda yang kebetulan menjadi birokrat, datang. Pemilik kuda yang disebut terakhir ini biasanya selalu disertai oleh melekatnya identitas-identitas kebirokratan, seperti kawalan atau iringan, sehingga memengaruhi suasana interaksi dengan komunitas yang dimasukinya.

Selama berada di arena pacuan kuda, informan Ngg, Bna, Ili, Bko, Bli, dan TionghoaTionghoa yang lain tidak mengambil tempat nonton di panggung tinggi, walaupun mereka dianggap sebagai kelompok dominan dalam kancah pacuan kuda. Merekalah yang memiliki kuda-kuda jago yang merajalela hampir di semua kelas. Mereka lebih suka berdesak-desakan dengan para penonton lain di panggung bawah, melakukan hal yang sama dengan penonton lain: bertaruh, menyoraki kuda, bercengkerama, berhamburan, berkeringat-keringat, makan di warung tenda, dan mempraktikkan budaya ujar yang sama dengan kalangan bawah ini. Mereka terlihat cair dan membaur dengan mayoritas komunitas Bima yang ada di arena pacuan kuda. Jika ada yang mencoba memperlakukan mereka secara berbeda, mereka selalu menampik. "Ndaike sama mpa ngupa ngaha ro ngupa sena" (kita di sini sama-sama cari makan dan cari kesenangan), ujar Bli berkelakar ketika menjawab olok-olok temannya orang Bima yang mengatakan dia pelit.

Etnik Tionghoa dikenal pintar dalam memasuki komunitas-komunitas lokal, dengan melakukan pendekatan melalui gaya ncabi (bersenda gurau), gaya eleganisme khas Bima. Misalnya dilakukan oleh Bko di Sape. Bko suka membuat ulah yang bisa mengundang ketawa para sahabatnya, seperti ulahnya ketika menjelang pacuan kuda. Ia mendatangi kandang kuda pacuan yang ada di sekitar wilayah Sape, kemudian ia semburkan kandang itu dengan air, layaknya seorang dukun sambil mengharap kuda-kuda itu tidak bisa lari, biar tidak menjadi saingan kudanya sendiri. Orang-orang yang punya kuda biasanya hanya ketawa saja. Setelah itu biasanya ia meminta kopi kepada sang pemilik kuda untuk menemani mengobrol mereka yang panjang. Ngopi bareng di kandang kuda ini adalah salah satu ruang publik komunikasi yang tanpa jarak sosial di Bima.

Entah disengaja atau tidak, rata-rata orang Tionghoa dalam komunitasnya selalu menjadi buah bibir karena keunikannya masing-masing. Perilaku unik ini selalu merepresentasikan kebaikan, kepolosan, dan keakraban di mata kalangan sekitarnya. Ili misalnya, selalu menjadi buah bibir karena perlakuannya kepada kuda-kuda jago miliknya. Jika memberi jamu kepada kudanya yang hendak masuk arena, ia suka memberi obat secara berlebihan sehingga mengherankan orang-orang sekitarnya. Jika ditegur, ia selalu bilang: "Kudamu apa? Ini kuda saya sendiri!" dengan gaya serius tetapi kelakar seperti orang mau menantang berkelahi. Fenomena ini membuat orang-orang yang ada di sekitarnya hanya bisa ketawa.

Orang Tionghoa di Bima memang dikenal pintar membangun pencitraan diri di mata publik melalui narasi-narasi keunikan pribadi seperti ini. Orang-orang di sekitarnya berperan menyebarkan cerita-cerita ini dari mulut ke mulut. Tanpa disengaja, cerita ini telah membentuk narasi publik dan persepsi pribumi mengenai pribadi orang-orang Tionghoa yang baik dan penuh persahabatan. Persepsi ini melahirkan keakraban mereka dalam bergaul sehingga seakan tidak ada sekat-sekat di antara mereka. Kedekatan sosial dengan pribumi 
melahirkan citra positif etnis Tionghoa dalam masyarakat. Hobi pacuan kuda yang sama antara warga etnik Tionghoa dengan masyarakat Bima telah meleburkan identitas mereka menjadi pencinta kuda. Semangat hobi yang sama seperti ini tanpa disadari telah membuat mereka lupa kalau di antara mereka berbeda etnik. Pada konteks inilah mereka secara tidak langsung mengkonstruksi identitas yang sama sebagai penduduk yang tinggal di Bima dengan hobi yang sama. Konstruksi identitas sosial berdasarkan kesamaan hobi seperti ini berkonstribusi menghadirkan komunikasi efektif sehingga konflik sosial yang berbasis rasial dapat ditekan.

Temuandiatasmenunjukkankecenderungan yang kuat dari warga etnik Tionghoa di Bima untuk menjadi atau paling tidak diakui sebagai orang Bima, sebuah ekspektasi sosial yang oleh Berger dan Luckmann dimaknai sebagai upaya mengkonstruksi identitas subjektif sembari mengaburkan identitas objektifnya yang asli (Berger \& Luckmann, 2012). Upaya yang dilakukan etnik Tionghoa untuk menjadi orang Bima secara sosial relevan dengan konsep "installing outsider insider" (Fox, 2008), khususnya installing outsider identity untuk menjadi inheren dengan insider identity.

Dianggap sebagai pendatang dan warga komunitas non-pribumi adalah sesuatu yang tidak menyenangkan. Hal inilah yang dirasakan oleh warga keturunan Tionghoa yang tinggal di Bima. Warga etnik Tionghoa merasakan ada ganjalan psikologis saat berinteraksi sosial di Bima ketika label Dou Cina (orang Cina) masih disematkan pada diri mereka. Di samping itu, label tersebut dirasa kontras dengan totalitas pengabdian dan persahabatan yang mereka jalani selama berpuluhan tahun hidup di Bima. Mereka ingin dianggap sebagai Dou Mbojo (warga Bima) meskipun sanad mereka tidak terbantahkan beretnik Tionghoa (wawancara dengan Bko, Juli 2020).

Upaya etnik Tionghoa untuk terlibat dalam kegiatan sosial dan budaya masyarakat lokal tidak hanya dijadikan sebagai momentum untuk mengasah pemahaman dan kepekaan terhadap kultur masyarakat Bima, tetapi juga dapat dimaknai sebagai strategi etnik Tionghoa dalam menjaga eksistensinya selama tinggal di Bima. Terlibat dalam aktivitas yang sama, hadir dalam suasana suka dan duka, dan menekuni hobi yang sama antara etnik Tionghoa dan Bima membuat intensitas komunikasi lintas etnik menjadi relatif tinggi, dan pada saat bersamaan terjalin hubungan emosional yang baik di antara mereka. Pada titik inilah kesamaan secara psikologis dan sosial dapat terwujud, dan kesadaran sebagai outsider dari etnik lokal ditransformasikan menjadi insider. Fenomena inilah yang oleh disebut sebagai upaya mengkonstruksi identitas etnik secara sosial dan psikologis tanpa terikat dengan batas-batas yang bersifat teritoris (Barth, 1969).

Untuk kepentingan itu, etnik Tionghoa di Bima terlihat lihai mengelola identitasnya di panggung depan. Mereka tidak pernah mengidentifikasi diri sebagai orang Tionghoa, karena yang ada dalam benaknya mereka adalah orang Bima yang berketurunan Tionghoa. Informan Afl (wawancara, 2019) misalnya selalu mengidentifikasi dirinya sebagai orang Bima yang memang lahir di Bima. Bahkan beliau dalam pembicaraannya sedapat mungkin mendemonstrasikan bahasa Bima yang khas. Informan Bso mengakui kalau dirinya adalah orang Bima dan sudah lama merasa jadi orang Bima. Bso mengatakan "kalau saya ketemu dengan orang Tionghoa saja kami pakai bahasa Bima 90 persen. Saya banyak lupa bahasa Tionghoa. Saya lahir di Sila karena ada aturan PP nomor 10 tahun $1957 \mathrm{itu}$, kami pindah ke kota Bima" (wawancara dengan Bso, 2019). Pengakuan polos informan di atas menunjukkan bahwa mereka memperlihatkan dirinya sebagai orang beridentitas Bima ketika berada di ruang publik.

Cara lain yang dilakukan etnik Tionghoa dalam mengkonstruksi dirinya sebagai warga Bima adalah dengan selalu menggunakan Bahasa Bima (Nggahi Mbojo) di ruang publik. Bahasa adalah identitas suatu daerah, maka penggunaan bahasa daerah tertentu menunjukkan upaya yang bersangkutan (penggunanya) untuk memperlihatkan dirinya sebagai orang yang beridentitas daerah tersebut. Semua informan selalu menggunakan Bahasa Bima ketika berdialog dengan peneliti. Bahkan Bahasa Bima yang digunakan adalah bahasa gaul yang pada umumnya digunakan oleh orang Bima. Bahasa Bima selalu digunakan oleh etnik Tionghoa saat mereka berinteraksi dengan masyarakat Bima di setiap ruang publik.

Penggunaan Bahasa Bima selama berinteraksi di ruang publik menunjukkan bahwa semua etnik Tionghoa mengidentifikasi 
dirinya sebagai orang Bima lewat bahasa yang mereka gunakan. Ketika ditanya langsung kepada yang bersangkutan (etnik Tionghoa), semua mengatakan bahwa mereka adalah orang Bima (bukan orang Tionghoa) karena mereka lahir di Bima, bisa berbahasa Bima, dan menikmati sebagai orang Bima. Ketika ditanya sense ke-Bima-an, mereka menjawab:

"Saya senang dipanggil dengan apa saja, dipanggil Tionghoa atau dipanggil Bima sama saja. Tapi saya sangat senang kalau disebut orang Bima. Kadang saya dipanggil muma oleh orang-orang, dan saya ketawa apabila mendengar panggilan seperti itu karena sangat senang. Tapi saya sering dipanggil baba. Apapun panggilan tidak ada masalah bagi saya" (wawancara dengan Bko, 2019)

"Iya lah Pak, kami inikan orang Bima, meskipun kami berasal dari keturunan Tionghoa. Kami lahir dan sejak kecil sudah di sini (Bima, pen.), bahkan kakek dan bapak kami sudah lama di Bima. Jadi apalagi yang membuat kami tidak mengatakan kalau kami ini orang Bima." (wawancara dengan Baa, 2020).

"Kalau saya ditanya begitu, pasti saya mengatakan kalau saya ini orang Bima. Lihat saja sendiri bagaimana saya sekarang. Saya pakai bahasa Bima, dan gak pernah kan saya pake bahasa Cina. Dalam KTP saya lahir di Bima. Jadi intinya saya orang Bima yang keturunan Tionghoa." (wawancara dengan Bna, 2019)

Identifikasi diri sebagai orang Bima merupakan pengakuan yang berulang disampaikan warga etnik Tionghoa. Pengakuan ini sekaligus menjadi harapan agar mereka diterima sebagai warga Bima dan diperlakukan sebagai saudara sendiri. Keinginan ini juga diperkuat oleh kemampuan dan kemauan mereka mempraktikkan bahasa Bima dalam keseharian di ruang publik. Berdasarkan pengamatan peneliti, etnik Tionghoa di Bima berbeda dengan etnik Tionghoa di daerah lain yang ada di NTB. Mereka selalu berbahasa Bima ketika berinteraksi dengan warga Bima di ruang publik, bahkan dengan logat yang sama dengan penduduk asli. Tradisi ini berbeda dengan keseharian yang ditampilkan oleh warga etnik Tionghoa yang ada di Kabupaten Sumbawa dan di Kota Mataram, Provinsi Nusa Tenggara Barat yang selalu berbahasa Indonesia ketika berinteraksi dengan masyarakat lokal.

Pilihan kata, konten, dan gaya bahasa Bima yang digunakan oleh etnik Tionghoa ketika berkomunikasi dalam komunitas terlihat egaliter. Para etnis Tionghoa menggunakan pola ujar orang Bima kebanyakan. Jika orang Bima kebanyakan suka membumbui atau menyelipkan pembicaraan dengan "umpatan" maka etnis Tionghoa juga menggunakannya dengan fasih. Ungkapan-ungkapan seperti: "fingi fanga" (tidak tahu malu), "datupa" (sembrono) dan beberapa umpatan lainnya sering terlontar secara refleks saat berkomunikasi. Gaya ujar seperti ini, dalam budaya interaksi masyarakat Bima, menunjukkan kedekatan dan egalitarian. Tidak sedikit di antara mereka yang suka $n c a b i$ (guyon) dengan masyarakat lokal. Mengenai $n c a b i$ warga etnik Tionghoa, seorang informan bercerita:

"Seringkali Baba Ko berkeliling kebun di belakang kampung di Sape, sekedar bercengkerama dengan para petani atau anggota masyarakat lain. Suatu saat, ia bertemu seorang petani yang sedang menggarap sawahnya, yang segera ditegur: "Hei, sudah minta izin, belum, menggarap sawah ini?," sahut Baba Ko kepada sang petani. Sang petani kebingungan. "Sawah ini sudah dijual sama bapakmu kepada saya, coba lihat surat-suratnya di rumah," kata Baba Ko lagi. Sang petani semakin bingung dan ketakutan. Di tengah suasana seperti itu biasanya Baba Ko memecah sendiri kebekuan itu, "Ayo, naik dulu kelapa itu, baru boleh garap sawah ini!," perintah Baba Ko sambil tertawa-tawa. Tahulah sang petani bahwa Baba Ko hanya berkelakar." (wawancara dengan Aht, 2019).

Pemilik salah satu perusahaan angkutan bus antardaerah di Bima, juga dikenal oleh para anggotanya sebagai pribadi yang hangat dan suka berkelakar. Dengan para pekerja dia selalu menggunakan cara komunikasi ala rakyat, dengan perintah-perintah keras diserta i'a (pisuhan). Ia tidak marah, hanya menunjukkan keakraban dan egalitarianisme pergaulan orang kecil. Gaya komunikasi etnik Tionghoa seperti 
ini telah menjadi realitas common sense bagi rakyat Bima, apalagi bagi karyawan toko dan para pelanggan mereka. Fenomena berbahasa Bima dengan logat dan imbuhan khas Bima yang dilakukan etnik Tionghoa semakin mempertegas pernyataan mereka (etnik Tionghoa) yang menyebut dirinya sebagai orang Bima. Di samping menjadi bagian dari meninstall identitas lokal, penggunaan bahasa daerah (Bima) juga dijadikan sebagai strategi etnik Tionghoa untuk mempererat hubungan dengan masyarakat Bima. Temuan ini relevan dengan hasil riset Makmur, Kuswarno, Novianti, dan Sjafirah yang menyebut komunikasi orang Tionghoa dalam bahasa Minang Pondok dapat mendukung terbentuknya saling pengertian dan hubungan yang lebih kondusif antara etnik Tionghoa dengan etnik mayoritas Minangkabau (Makmur et al., 2018).

Keinginan etnik Tionghoa di Bima untuk membangun kohesivitas dengan masyarakat lokal dan hasratnya untuk mengkonstruksi identitas etnik Bima dengan cara selalu berbahasa daerah mengkonfirmasi hasil riset Yee yang menyebut etnik Tionghoa sebagai pribadipribadi yang memiliki kemampuan berbahasa sebagai kemahiran kultural untuk kepentingankepentingan pragmatisnya di dunia sosial (Yee, 2004). Menurut Yee, warga Tionghoa bisa berekspresi dalam ber-apologi. Mereka bisa menggunakan bahasa secara fleksibel sesuai dengan motifnya, yang bisa membuat mereka rendah resistensinya (lowered resistance point) atau mampu membawa resistensinya pada titik terendah. Hasil riset Yee juga diperkuat oleh studi Seng yang secara spesifik mengkaji tentang kemampuan bisnis warga Tionghoa. Menurut Seng, dalam berkomunikasi dagang orang Tionghoa senantiasa memosisikan pelanggan adalah raja sehingga selalu menjaga komunikasi yang baik, berkompromi, fleksibilitas dalam bergaul sehingga dapat memuaskan semua orang (Seng, 2013).

Soal busana juga menjadi pertimbangan. Dalam hal busana warga etnik Tionghoa mengenakan pakaian seperti yang dikenakan oleh warga Bima umumnya. Pada saat santai, mereka juga mengenakan sarung khas Bima. Pakaian-pakaian khas Tionghoa tidak terlihat digunakan oleh etnik Tionghoa di ruang publik. Pilihan kostum yang sama dengan masyarakat Bima seperti ini menjadi cara mereka (etnik Tionghoa) menunjukkan kecintaannya terhadap budaya Bima. Pilihan kostum yang sama dengan kebanyakan yang dikenakan oleh warga Bima juga selaras dengan bahasa Bima yang selalu digunakan oleh mereka di ruang publik untuk menjalin ikatan dan membangun hubungan emosional di antara etnik berbeda identitas, sehingga jarak sosial menjadi tipis.

Pada konteks komunikasi, terjalinnya relasi sosial yang baik dan terbangunnya hubungan emosional di antara dua komunitas berbeda etnik menjadi modal penting dalam mewujudkan komunikasi efektif. Mulyana menyebut bahwa semakin sama latar dan kondisi sosial budaya seseorang maka semakin efektif komunikasinya (Mulyana, 2017). Interaksi yang lama antara etnik Tionghoa dengan masyarakat Bima telah berlangsung lama sehingga mereka bisa saling mengerti dan mengefektifkan komunikasinya. Temuan ini relevan dengan hasil riset Heryadi dan Silvana yang menemukan keakraban warga etnik Sunda dengan masyarakat Rejang disebabkan oleh adanya sikap saling memahami (Heryadi \& Silvana, 2013). Kesamaan yang terbangun saat komunikasi yang intens antara etnik Tionghoa dan Bima juga berpotensi menghilangkan prasangka dan stereotip antarbudaya. Effendy menyebut prasangka sebagai salah satu hambatan terwujudnya komunikasi efektif (Effendy, 2017), atau yang oleh Purwasito disebut sebagai hambatan potensial dalam komunikasi antarbudaya (Purwasito, 2015). Intensitas komunikasi antara etnik Tionghoa dan masyarakat lokal juga dapat memperbesar irisan kohesivitas di antara mereka sekaligus meminimalisir konflik sosial berbasis rasial, sebab konflik sosial terjadi antara lain dipicu oleh semakin memudarnya kohesivitas sosial yang tergerus banyak faktor seperti semakin berkembangnya sikap-sikap individualisme (Griffin et al., 2015).

Seluruh uraian dan analisis di atas secara eksplisit maupun inplisit menjelaskan tentang upaya installing identitas etnik yang dilakukan oleh warga Tionghoa dan fenomena komunikasinya dengan masyarakat Bima. Uraian panjang tentang proses dan strategi installing identitas etnik yang dilakukan warga Tionghoa tersebut dapat disederhanakan dalam bentuk model sebagaimana terlihat pada gambar 1 .

Model installing identitas etnik Tionghoa di Bima yang ada pada gambar 1 menunjukkan bahwa etnik Tionghoa dinilai sukses melakukan 


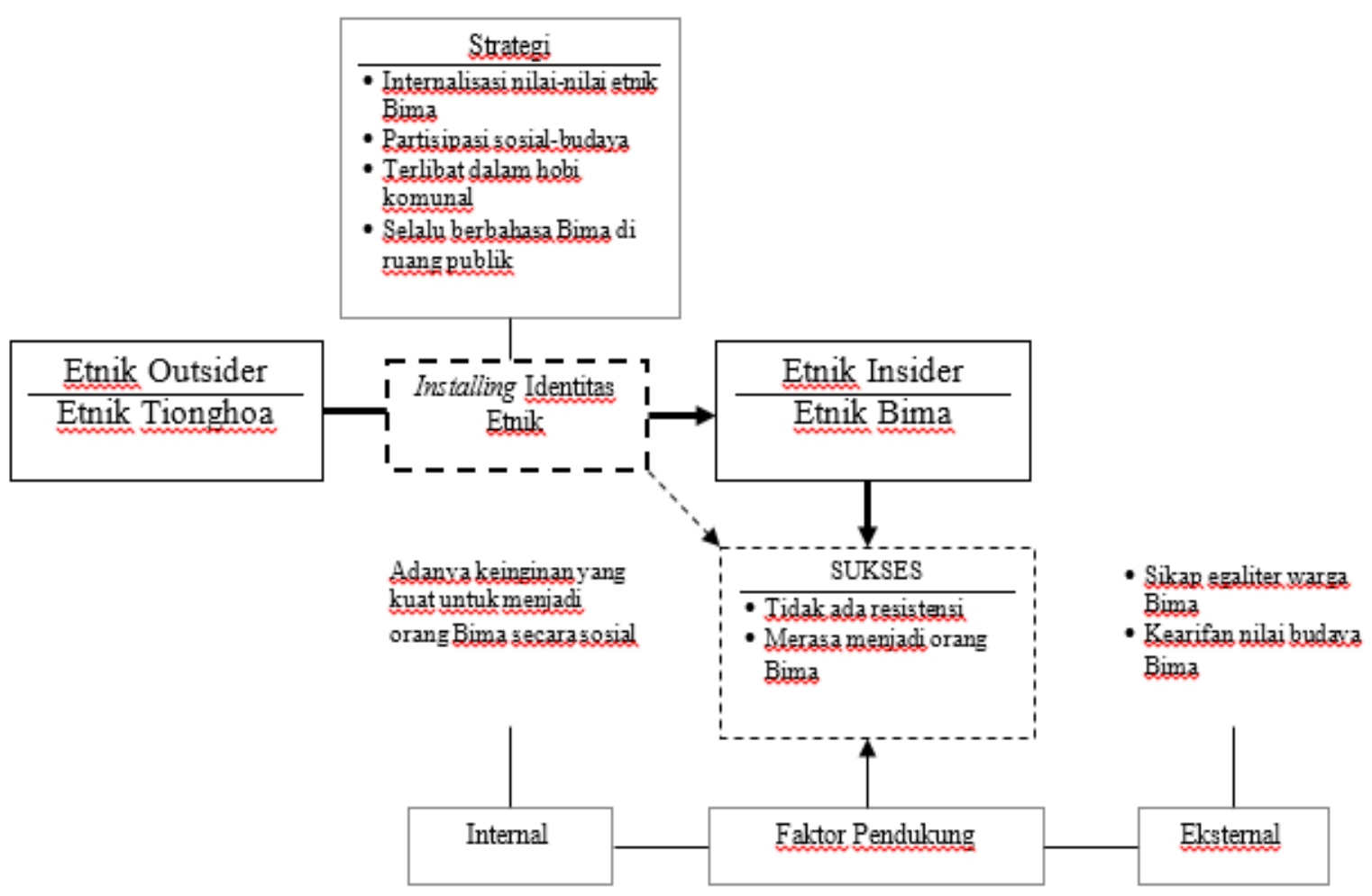

Sumber: Diolah dari hasil penelitian, 2020

\section{Gambar 1 Model Installing Identitas Etnik Tionghoa di Bima}

installing identitas etnik dengan indikator tidak ada resistensi keberadaan mereka dari warga lokal (indikator eksternal) dan adanya perasaan menjadi orang Bima (indikator internal). Etnik Tionghoa menggunakan setidaknya empat strategi saat melakukan installing identitas etnik, yakni menginternalisasi nilai-nilai etnik Bima, berpartisipasi secara sosial-budaya, terlibat dalam hobi komunal seperti pacuan kuda, dan selalu berbahasa Bima di ruang publik. Kesuksesan etnik Tionghoa melakukan installing identitas etnik tidak terlepas dari faktor internal berupa adanya keinginan yang kuat dari mereka untuk menjadi orang Bima secara sosial, dan support dari faktor eksternal berupa sikap egaliter warga Bima dan kearifan budaya Bima yang mengajarkan nilai harmoni.

Meskipun secara sosial dan psikologis warga etnik Tionghoa di Bima memiliki keinginan untuk menjadi orang yang beridentitas etnik Bima, tetapi keinginan tersebut masih ditunjukkan di ruang publik. Warga etnik Tionghoa memiliki ruang privat dengan pola pergaulannya sendiri sebagai ajang berinteraksi dengan kelompok-kelompok kecil seperti lingkungan keluarga, perhimpunan keluarga Tionghoa, atau komunitas pengusaha Tionghoa di Bima. Dalam ruang-ruang ini identitas keTionghoa-an eksplisit terlihat dan terdengar. Dalam situasi tertentu seperti di tokonya, etnik Tionghoa biasa berbahasa Tionghoa dengan anak dan suami/istrinya. Fenomena tersebut berbeda ketika mereka berada di ruang publik seperti di pasar atau di tempat lain di mana warga Bima berada.

Salah seorang warga Bima mengatakan bahwa warga etnik Tionghoa di Bima memiliki perkumpulan yang menjadi wadah mereka bertemu. Meskipun perkumpulan tersebut tidak terlalu aktif, tetapi dalam momen-momen tertentu mereka biasa bertemu, seperti ketika ada warga Tionghoa yang meninggal atau saat salah seorang dari anggota paguyuban memiliki hajatan tertentu, saat inilah mereka melakukan ritual khas warga Tionghoa dan berkomunikasi dengan bahasa Tionghoa yang tidak dipahami oleh warga Bima yang ada di sekitarnya atau yang mendengarnya (wawancara dengan Abt, 2020).

Informasi diatas menunjukkan bahwa 


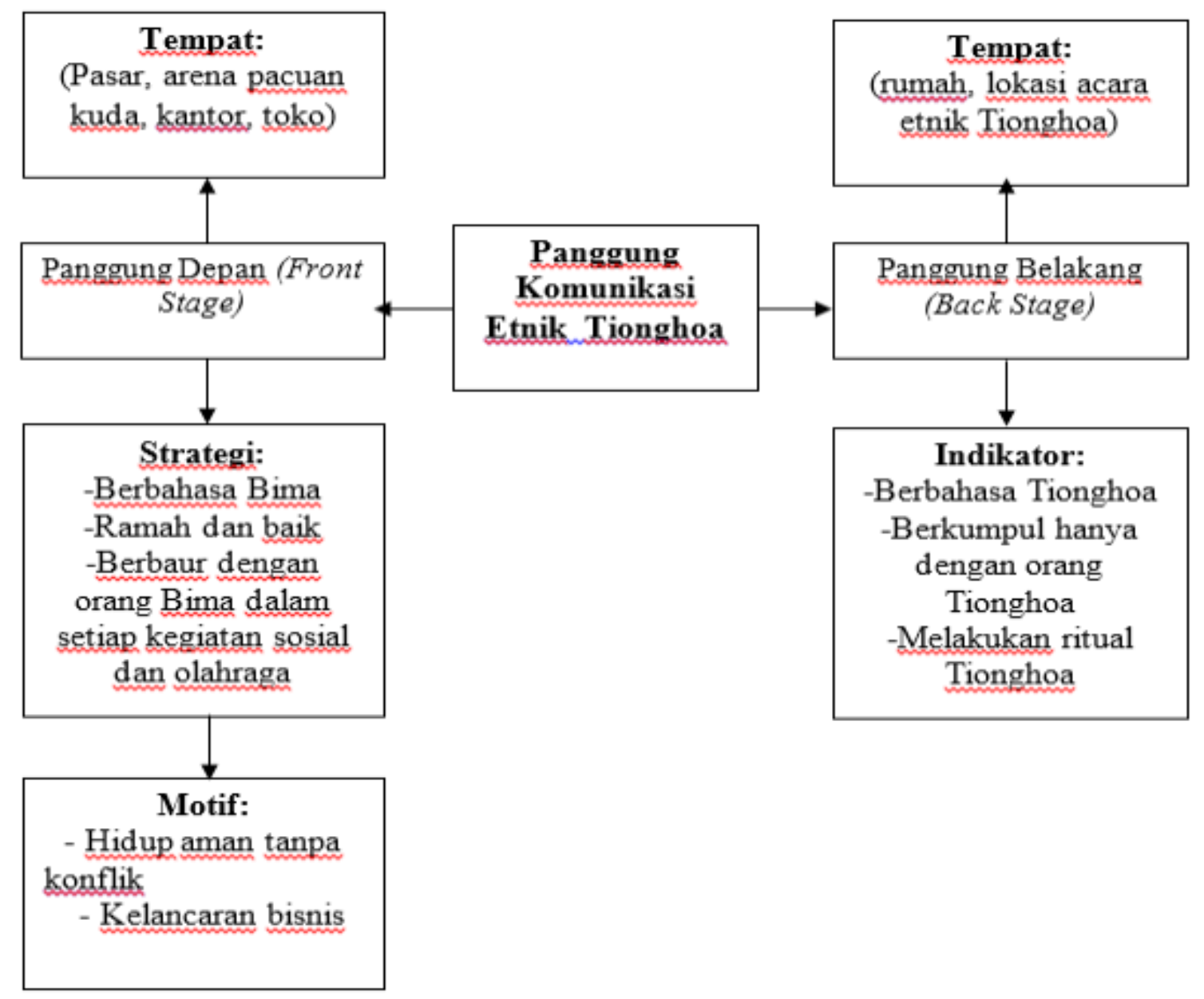

Sumber: Diolah dari hasil penelitian, 2020

Gambar 2 Model Pengelolaan Kesan Etnik Tionghoa

ada ruang tersendiri yang dijadikan sebagai panggung belakang bagi etnik Tionghoa Bima untuk mengekspresikan identitas keTionghoaan. Di panggung belakang inilah mereka menggunakan bahasa Tionghoa, bahasa yang sama sekali tidak pernah mereka gunakan saat berada di hadapan warga Bima di ruang publik. Kenyataan seperti ini mengisyaratkan masih adanya sikap ekslusivitas dan perasaan primordial sebagai orang Tionghoa, yang tentu saja kontras dengan pengakuannya di hadapan warga Bima bahwa mereka adalah warga Bima.

Temuan bahwa etnik Tionghoa hanya berbahasa Bima ketika bersama warga lokal di ruang publik dan menggunakan bahasa etnik sendiri di ruang privat menunjukkan bahwa kefasihan mereka dalam berbahasa daerah lebih didominasi oleh motif-motif pragmatis.
Motif-motif pragmatis dari warga Tionghoa dalam penggunaan bahasa daerah itu adalah pemenuhan kebutuhan untuk keamanan diri dan bisnis mereka. Komunikasi yang dilakukan etnik Tionghoa dalam bahasa daerah di Bima tidak lagi dinilai sebagai upaya yang total untuk menjadi warga Bima secara sosial. Pada konteks inilah etnik Tionghoa Bima melakukan pengelolaan kesan di ruang publik. Secara diagramatik, model pengelolaan kesan warga Tionghoa di Bima terlihat dalam gambar 2 .

Pengelolaan kesan etnik Tionghoa Bima mengkonfirmasi analogi teatrikal dari teori dramaturgi dari Goffman, yang membagi panggung kehidupan manusia menjadi dua yaitu panggung depan (front region) dan panggung belakang (back region) (Goffman, 1959). Etnik Tionghoa melakukan pengelolaan kesan di 
panggung depan dengan cara memperlihatkan diri sebagai orang Bima lewat bahasa dan perilakunya yang relevan dengan kultur masyarakat lokal. Pengelolaan kesan dari etnik Tionghoa dilakukan atas motif-motif pragmatis yang ingin etnik Tionghoa raih selama berada di Bima. Goffman mengatakan bahwa atas kesadarannya manusia dapat mengelola kesan tertentu di panggung depan untuk kebutuhan subjektifnya (Goffman, 1959).

Etnik Tionghoa melakukan hal tersebut dengan multi motif, seperti untuk mempertahankan kelangsungan hidup di tengah komunitas mayoritas (etnik Bima), sekaligus untuk mengamankan usaha dan bisnis yang digelutinya. Temuan riset ini memperkuat riset Ernawati dan Usman yang menemukan adanya motif ekonomi dibalik penggunaan bahasa Bima yang dilakukan oleh etik Tionghoa (Ernawati \& Usman, 2019). Memperlihatkan diri sebagai orang Bima merupakan pilihan yang aman untuk membangun emosional bersama orang Bima lainnya, sehingga di antara mereka tidak ada jarak dan saling menghormati serta saling menjaga.

\section{SIMPULAN}

Keinginan warga etnik Tionghoa untuk menjadi orang Bima secara sosial dan psikologis diimplementasikan dengan cara melibatkan diri dalam aktivitas sosial, mengambil bagian dalam hobi komunal masyarakat setempat, dan secara intens menggunakan bahasa setempat dalam komunikasi di ruang publik. Selama berinteraksi dengan warga Bima, etnik Tionghoa selalu mengafirmasi budaya setempat dan menggunakan bahasa daerah sebagai bagian dari upayanya memperlihatkan identitas dan kedekatannya dengan budaya lokal. Cara-cara ini merupakan strategi etnik Tionghoa dalam meng-install identitas yang awalnya dikenal sebagai outsider untuk menjadi bagian atau insider dari etnik Bima. Strategi installing identitas seperti ini juga terbukti bisa menghadirkan praktik komunikasi yang efektif antara etnik Tionghoa dengan warga Bima di ruang publik.

Meskipun upaya installing identitas outsider ke insider yang dilakukan etnik Cina dianggap mampu menciptakan komunikasi efektif dengan warga lokal, tetapi pertimbangan kepentingan pragmatis seperti keinginan untuk tetap dalam kesuksesan bisnis di Bima dapat diidentifikasi sebagai motif dominan dalam proses installing identity ini. Oleh karena itu, komunikasi etnik Tionghoa selama melakukan proses adaptasi identitas dinilai sebagai upaya pengelolaan kesan yang ditampilkannya di ruang publik untuk memenuhi motif-motif subjektif. Dengan demikian, etnik Tionghoa di Bima dinilai menerapkan strategi tindakan komunikasi berkepentingan untuk menginstall identitas etnik Bima dalam dirinya. Hal ini menyiratkan bahwa upaya etnik Tionghoa untuk menjadi orang Bima akan menjadi sebuah pergumulan yang terus menerus dalam mewarnai hubungan multikultural di Bima.

Upaya installing identitas etnik yang dilakukan oleh kelompok minoritas atau pendatang akan efektif bila didukung oleh sikap egaliter dari kelompok mayoritas atau masyarakat lokal dan adanya kearifan budaya lokal yang mengandung nilai-nilai harmoni. Model installing identitas etnik yang didukung oleh sikap egaliter warga lokal dan kearifan budaya setempat (lokal) seperti yang ditemukan dalam riset ini dapat dijadikan sebagai role model untuk membangun harmoni antaretnik di negara pluralis seperti Indonesia.

\section{DAFTAR PUSTAKA}

Barth, F. (1969). Ethnic groups and boundaries: the social organization of culture difference. Amerika: Little Brown.

Basundoro, P. (2012). Penduduk dan hubungan antaretnis di Kota Surabaya pada masa kolonial. Paramita: Historical Studies Journal, 22(1). https://doi.org/10.15294/ paramita.v22i1.1839.

Berger, P. L., \& Luckmann, T. (2012). Tafsir sosial atas kenyataan, risalag tentang sosiologi pengetahuan. Jakarta: LP3ES.

Effendy, O. U. (2017). Ilmu, teori, dan filsafat komunikasi. Bandung; Citra Aditya Bakti.

Ernawati, N., \& Usman, N. F. N. (2019). Pergeseran bahasa masyarakat etnis Tionghoa di Bima. MABASAN, 13(1), 31-44. https://doi.org/10.26499/mab. v13i1.246.

Fittrya, L. (2013). Tionghoa dalam diskriminasi orde baru tahun 1967-2000. Avatara, 1(2). https://jurnalmahasiswa.unesa.ac.id/index. php/avatara/article/view/2326. 
Fox, J. J. (2008). Installing the 'outsider' inside. Indonesia and the Malay World, 36(105), 201-218. https://doi. org/10.1080/13639810802267942.

Goffman, E. (1959). The presentation of self in everyday live. Cox \& Wyman Ltd.

Griffin, E., Ledbetter, A., \& Sparks, G. (2015). A first look at communication theory. McGraq-Hill International Edition.

Heryadi, H., \& Silvana, H. (2013). Komunikasi antarbudaya dalam masyarakat multikultur. Jurnal Kajian Komunikasi, 1(1), 95-108. https://doi.org/https://doi.org/10.24198/ jkk.v1i1.6034

Hidayat, M.A, \& Farid, M. (2021). "Strangers at home: identity negotiation practices among ethnic Chinese in Madura, Indonesia," The Journal of Society and Media, https:// journal.unesa.ac.id/index.php/jsm/article/ view/11244.

Juditha, C. (2015). Stereotip dan prasangka dalam konflik Etnis Tionghoa dan Bugis Makassar. Jurnal ILMU KOMUNIKASI, 12(1). $\quad$ https://doi.org/https://doi. org/10.24002/jik.v12i1.445.

Makmur, R., Kuswarno, E., Novianti, E., \& Sjafirah, N. A. (2018). Bahasa Minang pondok dalam komunikasi antarbudaya masyarakat Tionghoa Kota Padang. Jurnal Kajian Komunikasi, 6(2), 133-146. https:// doi.org/https://doi.org/10.24198/jkk. v6i2.15302.

Miles, M. B., Huberman, A. M., \& Saldana, J. (2014). Qualitative data analysis: a sourcebook of new methods: matthew b. miles and a. michael huberman (4 ed.). SAGE Publications. https://doi. org/10.3102/01623737008003329.
Mulyana, D. (2017). Ilmu komunikasi: suatu pengantar. Bandung: Remaja Rosdakarya.

Mulyana, D. (2018). Metodologi penelitian kualitatif: paradigma baru ilmu komunikasi dan ilmu sosial lainnya. Bandung: Remaja Rosdakarya.

Pranawati, R. \& Abubakar, I. ed. (2011). Kebebasan beragama dan integrasi sosial. CSRC UIN Jakarta.

Purwasito, A. (2015). Komunikasi multikultural. Pustaka Pelajar.

Putro, Y. A., Atmaja, H. T., \& Sodiq, I. (2017). Konflik rasial antara etnis Tionghoa dengan Pribumi Jawa di Surakarta Tahun 19721998. Journal of Indonesian History, 6(1). https://journal.unnes.ac.id/sju/index.php/ $\mathrm{jih} /$ article/view/20031.

Seng, A. W. (2013). Rahasia bisnis orang China. noura books. Mizan Publika.

Sobur, A. (2013). Filsafat komunikasi. Remaja Rosdakarya.

Titulanita, F., Sumardiati, S., \& W, M. R. E. (2015). Kerusuhan Pasar Glodok: studi kasus etnis Tionghoa di Kelurahan Glodok Kecamatan Taman Sari Jakarta Barat. Publika Budaya, 3(1), 10-19. https://jurnal. unej.ac.id/index.php/PB/article/view/1533.

Wahid, A. Du. (2015). Jara mbojo: kuda-kuda kultural. Dinas Pariwisata NTB.

Weng, H.W. (2019). Berislam ala Tionghoa: Pergulatan Etnisitas dan Religioositas di Indonesia. Mizan.

Yee, A. S. (2004). Semantic ambiguity and joint deflections in the hainan negotiations. China: An International Journal, 02(01), 53-82. https://doi.org/10.1142/ S0219747204000044. 